\title{
Liver Morphology and Morphometry and Plasma Biochemical Parameters of Wistar Rats that Received Leaf Infusion of Rudgea viburnoides Benth. (Rubiaceae)
}

\author{
Juliana Castro Monteiro*, Sérgio Luis Pinto da Matta, Fabrícia de Souza Predes and Tânia \\ Toledo de Oliveira \\ Departamento de Biologia Geral; Universidade Federal de Viçosa; Av. P.H. Rolfs s/n; 36570-000; Minas Gerais - \\ $M G$ - Brasil
}

\begin{abstract}
Rudgea viburnoides leaves are widely used in popular Brazilian medicine as a diuretic, antirheumatic, hypotensive and blood depurative tea. The present study was carried out to investigate the effects of this infusion on the liver and on the plasma biochemical parameters of Wistar rats. Two groups received the R. viburnoides leaf infusion at a daily dose of 10 or $20 \mathrm{~g}$ dry-leaves/L water, during 40 days. The histopathological analysis did not show degenerated areas or infiltration of leucocytes. Hepatic morphometry showed accumulation of fat in the hepatocytes of the treated groups. There was no significant change in the plasma levels of urea, creatinin, uric acid, direct bilirubin, cholesterol, total proteins, albumin, gamma glutamyl tranferase (gamma-GT), alanine transaminase (ALT), aspartate transaminase (AST), chlorine, phosphate and calcium. A significant reduction in the plasma levels of triacylglycerol (TAG) occurred in the group that received the higher dose.
\end{abstract}

Key words: "Congonha-de-bugre"; Rubiaceae; medicinal plants

\section{INTRODUCTION}

Rudgea viburnoides Benth. (Family Rubiaceae), commonly known as "congonhas-de-bugre", "cotó-cotó" and "chá-de-bugre", has been used for about three hundred years in popular medicine in Brazil, especially in the state of Minas Gerais (Alves et al, 2004; Alves et al, 2000; Brandão et al., 2000; Young et al., 1998) . Various parts of the plant possess different medicinal properties: the leaves are used to treat rheumatism, syphilis, tiredness, dyspepsia, swelling of the members, bladder and urinary tract diseases, high blood pressure and recently it has been indicated for weight loss diets; the root bark and stem are good for gout, the nocturnal sweating of tubercular patients, stomach ulcers, rheumatism, as well as a blood depurative; the ripe fruit rinds exhibited a moderate antifungal activity against Cladosporium cladosporioides (Moreira, 1983; Young et al., 1998; Alves et al., 2004).

Chemical examination of $R$. viburnoides plant revealed the presence of flavonoids, a new triterpene (viburgenin), saponins (arjunglucoside I and trachelosperosides B-1 and E-1) and other triterpenes (trachelosperogenin $\mathrm{B}$ and arjungenin) (Young et al., 1998; Alves et al., 2004).

\footnotetext{
* Author for correspondence: julianacmonteiro@yahoo.com.br
} 
Despite its medicinal use, there is a lack of investigations on the therapeutic efficacy of this plant, as well as studies to determine the toxic side effects. Controlled clinical studies are essential. The present work investigated the effects of the leaf infusion of $R$. viburnoides in the rats, providing preliminary biochemical data, morphometry and morphology of the liver.

\section{MATERIALS AND METHODS}

\section{Experimental Animals}

Adult Wistar rats, 100 days old, weighing 230-270 $\mathrm{g}$ were obtained from the Departament of Nutrition and Health bioterium (Federal University of Viçosa, Viçosa, MG, Brazil) and maintained in 12hrL: $12 \mathrm{hrD}$ conditions. The animals used in the experiment were kept and handled in accordance to Ethical Principles for Animal Research required by the Brazilian College for Animal Experimentation (COBEA). Animals were fed pelleted standard rat food, ad libitum.

\section{Plant material}

The leaves of $R$. viburnoides were collected from Congonhas (MG - Brazil) in May 2002. $R$. viburnoides was identified, authenticated and deposited in the Herbarium VIC at the Departament of Vegetal Biology, Federal University of Viçosa, Brazil, under the number 26,728. The leaves were shade-dried. An infusion of $R$. viburnoides was routinely prepared by pouring a liter of boiling water over the dried leaves (10 and 20g) that were allowed to steep for 20 minutes and filtered using filter paper. This produced an infusion of $3.166 \mathrm{mg}$ of extract dry weight per $\mathrm{ml}$ of infusion $(0.316 \% \mathrm{w} / \mathrm{v})$ and a yield of $32.153 \%(w / w)$ in terms of initial crude plant material dry weight.

\section{Treatment protocol}

Three groups of ten randomly selected animals were used. Group I and Group II received, in water bottles, $200 \mathrm{~mL}$ of $R$. viburnoides leaf infusion daily at a dose of 10 and $20 \mathrm{~g}$ dry-leaves/L water, respectively for 40 days. The control group received the same amount of water. The animals ingested $50 \mathrm{ml}$ of tea and water on the average. The dosages were selected to mimic the popular medicinal use.

\section{Preparation of tissue for microscopy}

Animals were anesthetized with ether and the abdomen and thoracic cavity was opened to expose the heart. Animals were subsequently perfusion-fixed by whole body perfusion, based on the method proposed by Sprando (1990). Hepatic tissue was refixed for $24 \mathrm{~h}$ in $2.5 \%$ glutaraldehyde in PBS and prepared for embedding in glycol methacrylate using standard techniques. Subsequently, $3 \mu \mathrm{m}$ thick sections were obtained and stained with toluidine blue/ $1 \%$ sodium borate.

\section{Morphological analysis and Morphometry}

Morphological and morphometrical analyses were performed using light microscopy. The proportion of various hepatic tissue components were determined by using a 121 -intersection grid placed in the ocular lens of an Olympus BX-50 light microscope. One thousand points were counted for each animal at a magnification of 1000 times. Points were classified as follows: normal hepatocytes, Kupfer cells, lipid droplets, sinusoid capillaries, portal vein and degenerated hepatocytes.

\section{Blood sample and Biochemical analysis}

Blood samples were collected by cardiac puncture using heparin-containing sterile disposable syringes. Plasma was separated by centrifugation (7100 x G for 15 minutes) and urea, creatinin, uric acid, direct bilirubin, cholesterol, triacylglycerol (TAG), total proteins, albumin, gamma glutamyl transferase (gamma-GT), alanine transaminase (ALT), aspartate transaminase (AST), chlorine, phosphorus and calcium levels were measured using Biolab kits.

\section{Statistical analysis}

All data were presented as the mean \pm SEM (standard error mean) and analyzed via ANOVA (Duncan test) by using the System for Statistical Analysis (SAEG 9.0). The significance level was $\mathrm{p}<0.05$.

\section{RESULTS}

\section{Liver morphology and morphometry}

The histopathological analysis did not show degenerated areas nor infiltration of leucocytes; portal tracts and central veins did show noticeable, but not significant alterations, when compared to 
the control group. Microscopic fatty deposits in the liver were observed in the treated animals. The liver morphometric analysis is presented in Table 1. The significant increased of lipid droplets was observed in the hepatocytes of the animals of group II and they were larger than in the other group (Fig. 1). As a consequence of fat accumulation, there was a reduction in the proportion of typical hepatocytes when groups I and II were compared $(\mathrm{p}<0.05)$. The sinusoid capillaries were $15.12 \%$ reduced in group I $(p<0.05)$ and $7.13 \%$ in group II $(p>0.05)$. There was no significant change in Kupfer cells and portal vein proportions in the treated animals.

Table 1 - Morphometrical analysis (volumetric density - \%) of liver tissue of Wistar rats treated with infusion of Rudgea viburnoides.

\begin{tabular}{lccc}
\hline & Control & Group I & Group II \\
\hline Normal Hepatocytes & $58.28 \pm 1.58^{\mathrm{ab}}$ & $59.22 \pm 1.89^{\mathrm{a}}$ & $53.89 \pm 1.66^{\mathrm{b}}$ \\
Kupffer cells & $11.38 \pm 1.01^{\mathrm{a}}$ & $11.14 \pm 0.58^{\mathrm{a}}$ & $9.93 \pm 1.01^{\mathrm{a}}$ \\
Sinusoid capillary & $27.78 \pm 0.34^{\mathrm{a}}$ & $23,58 \pm 1.34^{\mathrm{b}}$ & $25.18 \pm 0.65^{\mathrm{a}}$ \\
Lipid droplets & $0.25 \pm 0.25^{\mathrm{b}}$ & $1.84 \pm 0.98^{\mathrm{b}}$ & $8.75 \pm 3.18^{\mathrm{a}}$ \\
Degenerated hepatocytes & $0.00 \pm 0.00^{\mathrm{a}}$ & $0.00 \pm 0.00^{\mathrm{a}}$ & $0.00 \pm 0.00^{\mathrm{a}}$ \\
Portal vein & $1.72 \pm 0.93^{\mathrm{a}}$ & $4.22 \pm 2.41^{\mathrm{a}}$ & $2.25 \pm 2.25^{\mathrm{a}}$ \\
\hline
\end{tabular}

Values are mean \pm S.E.M. of ten rats. ${ }^{\text {a,b }}$, means, within the same rows, bearing different superscript letters are significantly different $(\mathrm{p}<0.05)$.
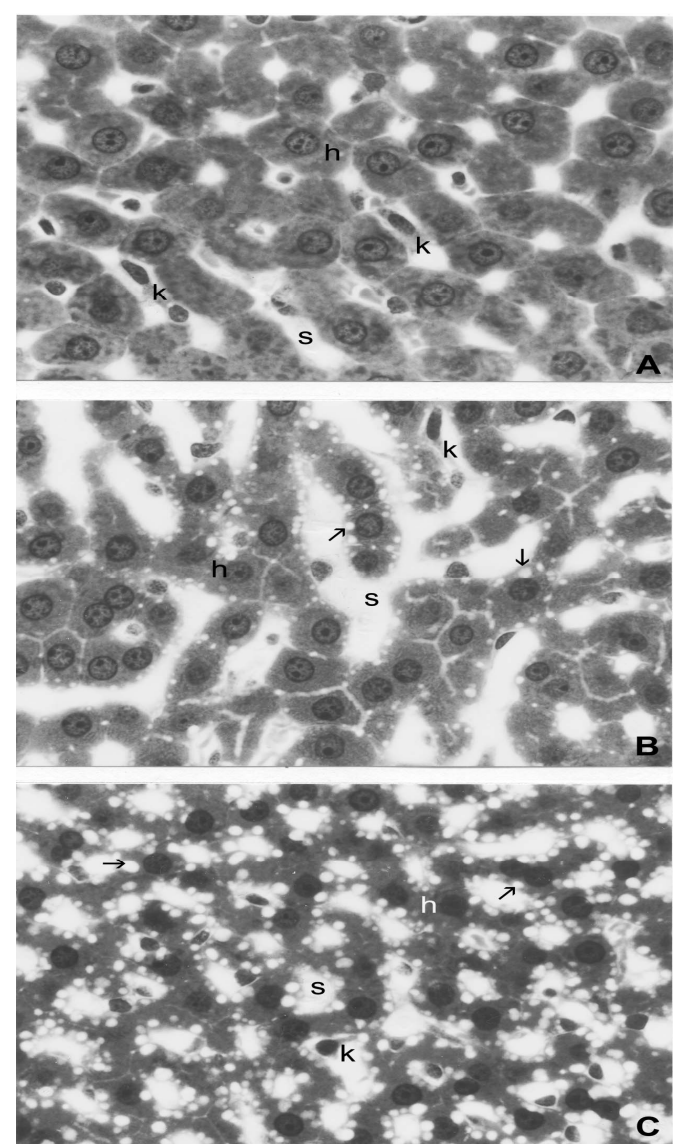

Figure 1 - Hepatic tissue of Wistar rats treated with different concentrations of $R$. Viburnoides leaf infusion. A- control group; B- group I; C- group II. $\mathrm{h}=$ cords of hepatocytes, $\mathrm{s}=$ sinusoid capillaries, $\mathrm{k}=$ Kupffer cell, arrows = lipid droplets. Toluidine blue $/ 1 \%$ sodium borate. X 540 . 


\section{Biochemical analysis}

There was no significant change in the urea, creatinin, uric acid, direct bilirubin, cholesterol, total proteins, albumin, gamma-GT, ALT, AST, chlorine, phosphate and calcium plasma levels (Table 2). A significant reduction $(\mathrm{p}<0,05)$ in the TAG levels occurred in the animals of group II(Table 2).

Table 2 - Biochemical plasma parameters of Wistar rats treated with infusion of Rudgea viburnoides.

\begin{tabular}{lccc}
\hline & Control & Group I & Group II \\
\hline Urea (mg/dL) & $52.23 \pm 4.54$ & $54.13 \pm 2.70$ & $60.92 \pm 5.07$ \\
Creatinin (mg/dL) & $0.69 \pm 0.04$ & $0.66 \pm 0.03$ & $0.69 \pm 0.03$ \\
Uric acid (mg/dL) & $1.24 \pm 0.012$ & $1.34 \pm 0.21$ & $1.20 \pm 0.14$ \\
Cholesterol (mg/dL) & $94.00 \pm 4.23$ & $92.80 \pm 3.40$ & $94.82 \pm 8.88$ \\
Triacylglycerol (mg/dL) & $42.14 \pm 2.35$ & $35.50 \pm 1.43$ & $33.47 \pm 3.17^{*}$ \\
Calcium(mg/L) & $10.99 \pm 0.37$ & $10.15 \pm 0.44$ & $9.96 \pm 0.29$ \\
Chlorine (mmol/L) & $122.97 \pm 1.96$ & $113.94 \pm 3.86$ & $117.24 \pm 4.72$ \\
Phosphate (mg/L) & $12.20 \pm 1.91$ & $12.80 \pm 3.07$ & $15.37 \pm 3.09$ \\
Total proteins (g/L) & $66.65 \pm 1.34$ & $64.81 \pm 1.25$ & $64.57 \pm 1.90$ \\
ALT (UI) & $95.60 \pm 5.14$ & $124.45 \pm 24.20$ & $118.90 \pm 23.45$ \\
AST (UI) & $84.60 \pm 8.93$ & $122.98 \pm 20.43$ & $82.70 \pm 7.98$ \\
Gamma-GT (UI) & $3.70 \pm 0.60$ & $4.45 \pm 0.50$ & $3.85 \pm 0.68$ \\
Albumin (g/dL) & $5.52 \pm 0.19$ & $5.31 \pm 0.20$ & $5.49 \pm 0.16$ \\
Direct bilirubin (mg/dL) & $0.14 \pm 0.01$ & $0.19 \pm 0.02$ & $0.18 \pm 0.03$ \\
\hline Valus ar mat
\end{tabular}

Values are mean \pm S.E.M. of ten rats. * $\mathrm{p}<0.05$ compared with control group.

\section{DISCUSSION}

In the experimental procedure, several biochemical dosages were used to evaluate the effects of the compound tested in the animals (Lima, 2000). The most commonly used plasma biochemical parameters to detect liver damage are ALT and AST as hepatocellular markers, and alkaline phosphatase (ALP) and bilirubin as hepatobiliary markers (Tennant, 1999). The rise in serum levels of AST and ALT has been attributed to the damaged structural integrity of the liver, since these enzymes are cytoplasmically located and released into the blood after cell damage (Janbas and Gilani, 2000). The animals treated here with $R$. viburnoides did not present significant alterations of AST, ALT, Gamma-GT, total protein, albumin and direct bilirubin content, indicating that this plant did not cause damage in the hepatocytes and the biliary system. On the other hand, it has been suggested that hepatic TAG is a key parameter to follow the progress of toxic damage in the rat, and it has been recommended that serum TAG determination may be useful as a non-invasive method (Danni et al., 1986). The results clearly showed that plasma TAG were decreased following the treatment with the infusion of $R$. viburnoides, and this decrease was accompanied by microscopic fatty droplets in the liver.

A decrease in body weight on some occasions may indicate a decrease in food consumption, which is known to result from a lowering of circulating TAG (Poullain et al., 1989). Although food consumption was not measured here, no reduction in body weight in the treated groups was observed (data not presented). Therefore, it was concluded that the decrease found for TAG was not likely to be a consequence of a reduction in food intake.

The studies reporting the liver toxicity tested for a various compounds showed that a number of molecular mechanisms might be involved in the lipid changes (Provost et al., 2003). The liver plays a central role in whole body lipid and carbohydrate metabolism. Disruption of the normal mechanisms for the synthesis, transport and removal of long chain fatty acids (LCFAs) and TAG are the basis for the development of steatosis (Anstel and Goldin, 2006). Steatosis is defined as an excessive accumulation of fat in the hepatocytes and involves the accumulation of triacylglycerol in the hepatocytes, apoptosis, hepatocellular balloning, Mallory's hyaline, necrosis of hepatocytes, lobular inflammation, small hepatic vein obliteration and often fibrosis with possible progression to cirrhosis, hepatocellular cancer and liver-related death (McCullough, 2004). Although, fatty 
deposits in the liver were dose-dependent in the treated groups, the histopathological analysis of the liver showed normal hepatic structure without inflammatory infiltration, central lobular necrosis nor congested central veins and fibrosis. Therefore, this liver contained fatty deposits that could not be characterized as steatosis.

Most peripheral lipid effects involve, either directly and indirectly, a change in the metabolic function of the liver and is consequent to (1) an impairment of lipid synthesis, (2) an impairment of transportation due to effects on lipoproteins synthesis, and (3) an accelerated catabolism of lipids in the liver or other tissues (Provost et al., 2003). Although, the present study did not show a reduction in circulating cholesterol and the total protein levels remained unchanged, there could have occurred a deficiency in the production of apolipoprotein, a complex responsible for the transport of TAG out of the liver.

In conclusion, this study showed that the $R$. viburnoides leaf infusion resulted in a decrease in plasma TAG after 40 days of treatment. These changes were not related to a reduction in food consumption but correlated to microscopic changes in fatty deposits demonstrated in the liver.

\section{ACKNOWLEDGEMENTS}

The authors would like to acknowledge Dra. Heidi Dolder (Department of Cell Biology UNICAMP) for correcting the English and Laboratório de Biofármacos (UFV) for the biochemical parameters analysis.

\section{RESUMO}

As folhas de Rudgea viburnoides Benth. são utilizadas na medicina popular como diuréticas, hipotensoras, anti-reumáticas, depurativas do sangue e em regimes de emagrecimento. $\mathrm{O}$ presente estudo foi delineado para avaliar o efeito da infusão das folhas de $R$. viburnoides nos parâmetros bioquímicos plasmáticos e na morfologia e morfometria hepática de ratos Wistar adultos. Dois grupos receberam a infusão das folhas, diariamente, nas dosagens de 10 e $20 \mathrm{~g}$ de folhas secas/L de água, durante 40 dias. $\mathrm{O}$ grupo controle recebeu a mesma quantidade de água. As análises histopatológicas não mostraram áreas degeneradas e infiltrados inflamatórios. A morfometria hepática mostrou acúmulo significativo de gordura nos hepatócitos dos animais tratados, principalmente no grupo que recebeu a maior dose da infusão $(8,75 \%$ de gotículas lipídicas), comparado com $0,25 \%$ delas encontradas nos animais controles. Não foram observadas alterações nos níveis plasmáticos de uréia, creatinina, ácido úrico, bilirrubina direta, colesterol, proteínas totais, albumina, gamaglutamil transferase (GGT), alanina transaminase (ALT), aspartato transaminase (AST), cloro, fósforo e cálcio. Foi observada redução significativa de $20,6 \%$ nos níveis plasmáticos de triacilglicerol no grupo que recebeu a infusão mais concentrada, comparada aos animais controle.

\section{REFERENCES}

Alves, R. M. S.; Stehmann, J. R.; Isaias. R. M. S.; Brandão, M. G. L. (2004), Caracterização botânica e química de Rudgea viburnoides (Cham.) Benth., (Rubiaceae). Revista Brasileira de Farmacognosia, 14, 49-56.

Alves, T. M. A.; Silva, A. F.; Brandão. M.; Grandi, T. S. M.; Smânia, E. F. A.; Smânia Júnior, A.; Zani, C. L. (2000), Biological Screening of Brazilian Medicinal Plants. Memorias Instituto Oswaldo Cruz, 95, 367-373.

Anstee, Q.M. and Goldin, R.D. (2006), Mouse models in non-alcoholic fatty liver disease and steatohepatitis research. International Journal of Experimental Pathology, 87, 1-16

Bradbury, M. W. and Berk, P. D. (2004), Lipid metabolism in hepatic steatosis. Clinical Liver Disease, 8, 639-671.

Brandão, M. G. L.; Fernandes, I. N.; Santana, F. C.; Santana, P. C.; Bernardes, L. (2005), Circuito de plantas medicinais e aromáticas de Belo Horizonte. Anais do $8^{\circ}$ Encontro de Extensão da UFMG, 3-8 october, Belo Horizonte, Brazil.

Danni, O., Brando, C., Burldino, E. (1986), A model for monitoring changes in liver function. Research Commun Chemical Pathology and Pharmacology, 54, 395-403.

Janbas, K. H.; Gilani, A. H. (2000), Studies on preventive and curative effects of berberine on chemical-induced hepatotoxicity in rodents. Fitoterapia, 71, 25-33

Lima, L. R. P. (2000), Efeitos farmacológicos, toxicológicos e mecanismo de ação de flavonóides e corantes naturais extraídos do urucum no metabolismo lipídico de coelhos. M.S. Thesis, Federal University of Viçosa, Viçosa, Brazil 
McCullough, A. J. (2004), The clinical features, diagnosis and natural history of nonalcoholic fatty liver disease. Clinical Liver Disease, 8, 521-533

Moreira, F. (1983), As plantas que curam. Hemus, São Paulo.

Poullain, M. G., Vacher, D., Cezard, J. P. (1989), Serum lipids in the rat refed after starving. Influence of the molecular form of nitrogen-protein, peptides or free amino-acids. Metabolic Clinical Experimental, 38, 740-744.

Provost, J. P., Hanton, G., Le Net, J. L. (2003), Plasma triglycerides: an overlooked biomarker of hepatoxicity in the rat. Comparative Clinical Pathology, 12, 95-101.

Sprando, R. L. (1990), Perfusion of the rat testis through the heart using heparin. In: Histological and
Histopathological Evaluation of the Testis, ed. L. D. Russel, R. Ettlin, A. P. Sinha Hikim; E. D. Clegg. Cache River Press, Clearwater, pp. 277-280

Tennant, B. C., (1999). Assessment of hepatic function. In: Clinical biochemistry of laboratory animals, ed. Loeb, W.F., Quimby F.W. Taylor and Francis, London, pp. 501-517

Young, M. C. M.; Araújo, A. R.; Silva, C. A.; Lopes, M. N.; Trevisan, L. M. V.; Bolzani, V. S., (1998), Triterpenes and saponins from Rudgea viburnoides. Journal of Natural Products, 61, 936-938.

Received: September 18, 2006; Revised: April 30, 2007; Accepted: June 16, 2008. 